\title{
Challenging the Gospel of Neoliberalism? Civil Society Opposition to Mining in Armenia
}

\begin{abstract}
This article examines the introduction of neoliberal policies in the mining sector in Armenia and the civil society resistance that has emerged against those policies and practices. While recognising that neoliberal policies have global reach, I examine how neoliberal policies are locally translated, manifested, and resisted in Armenia and what factors shape resistance to neoliberal policies. I argue that the anti-mining activists have created new subjectivities and spaces for activism where they resist and challenge neoliberal policies and practices in the mining sector as well as the heretofore accepted formal practices of civil society advocacy and engagement in policy processes. Although the activists have not changed the way mining is practiced in Armenia, they have opened up debates around mining, and neoliberal policies more generally, and created new understandings and practices of civic activism and citizenship in Armenia.
\end{abstract}

Key words: civil society, protest groups, democracy, neoliberalism, mining, Armenia

\section{Introduction}

When Armenia gained independence from the Soviet Union in 1991, the government at the time, which was led by President Levon Ter-Petrossian, introduced policies to privatise and liberalise the economy but it left the mining sector under state control. In February 1998, less than two years into his second term in office, Ter-Petrossian was forced to resign from office in what some have described as a bloodless "constitutional"(Walker, 1998: 1) or "velvet" coup (The Economist, 1998: 54). In 1999, his successor, Robert Kocharian, began privatising the mining sector and introducing policies, including a 'lenient' taxation system, low regulation, and no quantitative trade restrictions or the conversion of capital, so as to attract foreign direct investment (Rumin, 2000). By 2005 Armenia was considered to have 'the most favourable' investment climate in Central Asia and the Caucasus (Metal Bulletin, 2005, Mining Journal, 2005). 
In recent years, studies of extractive industries and their role in development in Africa, Latin America, and the Asia-Pacific have proliferated and scholars have examined the civil society resistance against mining policies and practices throughout the global South (Ali and Grewal, 2006, Banks, 2014, Bebbington et al., 2008b, Çoban, 2004, Conde and Kallis, 2012, Dougherty, 2011, Gordon and Webber, 2008, Holden, 2005, Hurley and Ari, 2011, Kuecker, 2007, Moody, 2007, O'Connor and Bohorquez Montoya, 2010, Padel and Das, 2010, Rasch, 2012). Within this growing body of literature, however, very little has been written about the anti-mining movements which have emerged in the post-socialist countries of Eastern Europe and the former Soviet Union (Velicu, 2012) and whether or how these movements are connected to or influenced by anti-mining struggles in other parts of the globe. In this article I examine the introduction of neoliberal policies in the mining sector in Armenia and the civil society resistance that has emerged against those policies and practices. I define civil society as an "arena for uncoerced social action" (Centre for Civil Society, 2010) and according to this definition, professionalised non-governmental organisations (NGOs), as well as protest groups, advocacy coalitions, political parties, and social movements are all part of civil society. While recognising that neoliberal policies have global reach, it is important to ask how specific local histories and conditions affect how these policies are manifested, understood, and resisted in particular places. Drawing on Ong's work on neoliberalism which challenges totalising narratives of neoliberalism and considers how neoliberalism is manifested in particular local contexts (Ong, 2006), I ask how are neoliberal policies locally translated, manifested, and resisted in Armenia and what factors shape that resistance. I agree with Hemment (2012) who argues that post-socialist countries are fertile sites from which to investigate neoliberalism because such analyses allow us to move away from abstract discussions of neoliberalism as an ideology and to examine actually existing neoliberalism. In examining the resistance to mining, I analyse the 
relationship between natural resource extraction, neoliberalism and civic activism and consider how understandings and practices of civic activism and social mobilisation are changing in Armenia. Resistance to mining in Armenia is entirely organised and led by urban based groups locally known as 'civic initiatives' (qaghaqaciakan naxad'er'nowt'yownner). ${ }^{1}$ Civic initiatives are distinct from NGOs in that they are informal, volunteer-based, horizontally structured and loosely organized groups which do not receive any funding from donors or the government.

Focusing on the campaign to stop the copper molybdenum mine in Teghut Forest, I examine how resistance to neoliberal policies and practices in the mining sector in Armenia is shaped by its experience of state socialism and the politics of the post-socialist transition. The campaign to stop the mining in Teghut, which is led by the Save Teghut Civic Initiative (STCI), is the largest and longest running anti-mining campaign in the country (2007-present) and which, according to one of my respondents has become the 'epicentre of environmental activism in Armenia' (Parkev). I argue that the activists involved in STCI, who are primarily young (20s-30s), middle class professionals who reside in the capital Yerevan, have created new subjectivities and spaces for activism where they resist and challenge neoliberal policies and practices in the mining sector as well as existing forms of civic activism by embracing more radical forms of action than the heretofore accepted formal and consensus-driven practices of NGO advocacy. Activists describe mining as the 'theft' (koghopowt) or 'plunder' (t'alan) of Armenia's natural resources and assert their right and responsibility, as citizens, to have a voice and play a role in development processes regardless of where they reside in the country. The activists describe their activism as a form of self-organisation and an expression of 'self-determined' citizenship and their campaign as a struggle against the relentless over-exploitation of natural resources and for the protection of Armenia's natural

\footnotetext{
${ }^{1}$ I have used the Hayastan transliteration application for transliterating Eastern Armenian terms into Latin script. http://www.hayastan.com/translit/
} 
resources, public property, democracy and human rights (Save Teghut Pamphlet 2014). Their protests are targeted towards both the international development agencies, which finance mining projects and support the adoption of neoliberal policies, as well as the Armenian Government which they see as acting in complicity, through the adoption of those policies, in legalising the 'plunder'.

Although the activists did not stop the opening of the Teghut Mine, which officially opened in December 2014, I maintain that their campaign should not be seen as a failure. On the contrary, while it has become clear that the struggle against mining, which involves challenging the interests of very powerful actors (e.g., international development agencies, mining corporations and oligarchs) and projects where billions of dollars are at stake, cannot solely be won through small, urban based civic initiatives, I argue that STCI, as the first civic initiative to emerge in Armenia, has played an instrumental role in introducing more contentious forms of collective action and challenging the heretofore accepted nonconfrontational, consensus-driven practices of civil society advocacy and campaigning. Since 2010, the more contentious practices that were first introduced by STCI have been taken up with greater success by other civic initiatives on non-mining issues (Ishkanian 2015) I maintain that the emergence of STCI and its use of direct action represents a new phase of democratic politics in Armenia. The politics of 'dissensus' (Ranciere 2010) embraced by STCI activists challenges the reigning post-political consensus and seeks to replace it with a form of engagement which is centred on contestation and deliberation. Critical scholars describe post-politicisation as a process that emerged in the period of late capitalism in which the hegemony of neoliberal ideas led to the systematic foreclosure of the political and its replacement by consensual approaches (Mouffe, 2005, Ranciere, 2010, Zizek, 1999).

In examining the rise of the STCI-led anti-mining campaigning in Armenia, this article contributes to the studies of pro-democracy movements from around the globe and 
how they challenge authoritarian rule as well as neoliberal policies, practices and sensibilities (i.e., the post-political consensus). As part of this special issue on "Protest, Social Movements and Global Democracy" this article contributes to the discussions of how protest groups and social movements across the globe are confronting neoliberal policies and demanding greater democracy. In Armenia, as in much of the former socialist countries, the struggles against neoliberalism and for real democracy are relatively new (Evans Jr., 2012, Lutsevych, 2013, Niktin, 2010). While these movements' tactics, strategies and repertories of action (e.g., use of social media, etc.), as well as their discourses are partly shaped by current global practices and trends, they are also influenced by the legacy of socialism and the politics of the post-socialist transition. Thus on the surface the protest groups in the former socialist countries may appear to share similarities with movements beyond the region, there are also key differences. For example, several Occupy movements emerged in the postsocialist countries in 2012, including Occupy Mashtots Park in Armenia, Occupy Abai in Russia, and Occupy Slovenia, while they challenged the lack of democracy and growing corruption and oligarchic rule in their respective countries, unlike their North American or Western European Occupy counterparts, these movements also shied away from embracing an overtly left critique or vocal anti-capitalist stance (Glasius and Ishkanian 2015). This

reluctance is partly due to the toxic legacy of state socialism which still makes it very difficult for activists to formulate a left discourse or critique of capitalism (Razsa and Kurnik, 2012) (Ishkanian 2015).

\section{Methodology}

I have been conducting research in Armenia for many years (Ishkanian 2008), but this article is based on field research conducted in Armenia in four separate visits in September 2011, May 2012, October 2012, and November 2013 where I conducted eighty five in-depth, semi-structured interviews with the following: activists involved in the STCI; representatives 
of environmental and human rights NGOs; community members living in the two villages adjacent to the Teghut mine (Shnogh and Teghut); journalists; and representatives from donor organisations. Despite several attempts to interview a representative from the Armenian Ministry of Nature Protection, all requests were refused. In 2015, I also conducted follow-up Skype interviews with key STCI activists to assess the impact of the mine opening on the group. Based on my long years of research in Armenia, I have developed strong contacts with a variety of civil society actors and within academic circles in Armenia. Through these contacts, I was able to arrange the interviews with the abovementioned civil society stakeholders (e.g., NGOs, donors, activist groups, etc.). Activists involved in STCI assisted in arranging interviews with community members living in the villages of Teghut and Shnogh.

Questions focused on demands, targets and aspirations; tactics and repertories of action; and the relationships between activists with other stakeholders including local communities, NGOs, etc. The vast majority of interviews were conducted in Armenian with the remainder in English. Each interview lasted between sixty and ninety minutes. All interviews were recorded and transcribed. In addition to the aforementioned interviews, my research team and I organised fifteen focus groups (ten participants in each mixed-sex group) so as to understand attitudes towards mining, environmentalism, and civic activism. ${ }^{2}$ The focus group meetings were held in Yerevan and in the villages and towns in the provinces of Lori and Syunik where there is intense mining activity. In addition to the above, I conducted an extensive review of Armenian NGO and think tank publications as well as the Save Teghut Facebook page in order to understand the broader discourses and discussions around mining and environmental activism in Armenia.

\footnotetext{
${ }^{2}$ The focus group participants were recruited by my local research partners.
} 


\section{Mining, Neoliberalism and Civil Society Resistance}

In Armenia, and indeed internationally, international development agencies encourage developing countries to embrace mining as a strategy for economic growth and poverty reduction (World Bank, 2002, EBRD, 2012, Gordon and Webber, 2008, Bebbington et al., 2013) and support the introduction, and where necessary the reform, of regulatory frameworks to attract foreign direct investment. Subsequently, beginning in the 1980s, mining began to move from the global North to the global South, as foreign investors, seeking to increase their comparative advantage, were attracted by the less stringent environmental policies and regulatory frameworks in developing countries (Dougherty, 2011, Moody, 2007). Scholars studying anti-mining movements around the globe argue that protests are in opposition to the introduction of neoliberal policies or new forms of imperial expansion (Gordon and Webber, 2008, O'Connor and Bohorquez Montoya, 2010, Bridge, 2004, Hurley and Ari, 2011, Kuecker, 2007). They maintain that these protests are more than disputes over the distribution of rent and that resistance to mining is over the "meaning of development' (Bebbington et al., 2008a: 901) and in defence of traditional livelihoods, ancestral lands, and indigenous rights (Çoban, 2004, Padel and Das, 2010, Rasch, 2012). International experience demonstrates that campaigns which succeed in changing mining policies or practices are those which have the support of a wide set of allies both domestically and internationally (The Ecologist, 2013, Dougherty, 2011, Kuecker, 2007, Holden and Jacobson, 2008, Çoban, 2004) including the support of local communities, trade unions as well as populist, left or centre-left political parties (Gordon and Webber, 2008) and have the right to legally challenge policies (Sieder, 2010). As I shall demonstrate, none of these factors were present in the Armenian case and the lack of support from local communities, political parties and environmental NGOs subsequently shaped the outcome of the campaign against the Teghut mine. The protests against mining in Armenia are not just about the environment; 
they are about human rights and democracy, which is understood as voice, participation, and control.

In Armenia, as in a number of other Soviet republics (e.g., Georgia, Ukraine, etc.) environmental movements emerged in the mid-1980s. These movements were tolerated by the Soviet authorities who did not see them as 'posing any great danger to the regime' (Abrahamian, 2005: 253) but subsequently, they became 'surrogate movements' for more politically sensitive goals including ending the Communist Party's control (Henry, 2002: 186). In the post-Soviet period neoliberal policies were introduced as part of the 'transition' programmes and the mining sectors in many former socialist countries (e.g., Armenia, Kyrgyzstan, Romania) were privatised and de-regulated (Salmi, 2008, Weinthal and Luong, 2006). I define neoliberal policies as those which advocate privatisation, liberalisation, deregulation, the withdrawal of the state and the infiltration of market-driven calculations in the design and implementation of social policy (Harvey, 2007, Hilgers, 2012, Ferguson, 2009, Ong, 2006). Much has been written on why neoliberal policies have been promoted and how these policies alter the relationship between citizens and the state (Barry et al., 1996, Hilgers, 2012, Wacquant, 2012). In the context of development, Haque argues that neoliberal state formations have significantly changed the meaning and composition of citizenship, especially in terms of 'eroding rights or entitlements of citizens' (Haque 2008: 12). While natural resource extraction is not only a feature of neoliberalised economies, as Bebbington et. Al. point out, 'neoliberal reforms have clearly facilitated investment' in mining (Bebbington et al., 2013: 11). In recent years, 'inclusive liberalism' has been promoted as a corrective to market liberalism (Porter and Craig, 2004) and is presented as the 'direct successor' of neoliberalism in that it continues to promote a preference for market-based solutions, whilst recognising the need to "ameliorate the worst excesses and omissions of freemarket capitalism" (Gooloba-Mutebi and Hickey, 2010: 5). There has been much debate 
whether this approach is simply window-dressing and a continuation of policies which have been depoliticising and disempowering for poor people or if it can lead to a more progressive politics in the context of development (Hickey, 2010). In the former socialist countries of Eastern Europe and the Soviet Union, neoliberal policies were introduced in the 1990s with the objective to liberalise, privatise and deregulate the centralised economies and to help them make the 'transition' to a market economy (Marangos, 2002, Wedel, 1998). As Mandel argues, the development aid and technical assistance to the former socialist countries arrived ‘ideologically packaged' (Mandel 2012: 224) and the inevitability and desirability of the capitalist market was never questioned (Velicu, 2012). In the post-Soviet period it has been very difficult to challenge neoliberal economic policies in these countries, which have been viewed as gospel truths (Mandel 2012), above reproach and beyond critique.

But of course the transition project in Armenia and the other former socialist countries was not only about building a market economy; it was also concerned with building democracy. Beginning in 1990, donors, in a bid to build democracy, funded programmes promoting good governance, civil society, free and fair elections, human rights, and the rule of law (Carothers, 1999, Hansen, 1996). Civil society in particular was perceived as both a means and an end as donors embraced the idea that civil society is critical to democratization and good governance (US Agency for International Development, 1999, World Bank, 2004). Donors anticipated that civil society organisations, or more precisely, non-governmental organisations (NGOs), would take over the delivery of services, engage in advocacy and policy dialogue, and promote participation (Sampson, 1996). The model of civil society which was promoted in the former socialist countries is what Kaldor calls the 'neoliberal version' of civil society in which civil society restrains state power and also substitutes many of the functions performed by the state (Kaldor, 2003: 9). 
While donor support for civil society in the former socialist countries led to the rapid and 'explosive' growth in the number of NGOs in the 1990s (US Agency for International Development, 1999), scholars have demonstrated how NGOs across this region are perceived as donor driven, upwardly accountable, and disconnected from their own communities and constituencies (Babajanian, 2005, Bojicic-Dzelilovic et al., 2013, Greenberg, 2010, Hemment, 2004, Mendelson and Glenn, 2003, Mandel, 2002). Not only are there low levels of participation, but there is widespread lack of trust in NGOs (Celichowski, 2004, Greenberg, 2010, Evans Jr., 2012, Morjé Howard, 2003). Although many hoped that after 1991, because of greater political opportunities and access to resources, the Soviet-era environmental movements would grow in strength so as to hold powerful actors to account, scholars studying environmental NGOs and movements in this region argue that these actors have largely failed to generate participation (Císař, 2010, Henry, 2010) and that their actual empowerment and ability to influence policy has been disappointing (Carmin and Fagan, 2010, Henry, 2002). In Armenia, the environmental movement which emerged in 1986 and attracted wide national support (Malkhasian 1996), fell into disarray after independence as environmental concerns took a backseat to more pressing issues including recovery from the devastating 1988 Spitak earthquake and the impact of the war and blockade with Azerbaijan (1990-1994). In recent years the thirty-five registered environmental NGOs in the country (Counterpart International, 2010) have primarily been involved in non-confrontational forms of policy advocacy including conducting research, issuing reports, and engaging in dialog with policy makers. While these activities have been important in developing a knowledge base about mining activities in the country, the main challenge to mining in the country has come from the STCI and other civic initiatives, including the Pan Armenian Ecological Front.. Unlike the environmental NGOs, civic initiatives have adopted more radical and contentious forms of action to challenge the neoliberal mining policies and practices in 
Armenia as well as to critique the existing consensus-driven forms of civil society engagement. Before turning to discuss the resistance to mining in Armenia, I present the governance context and policy framework.

\section{The Governance Context and Mining Friendly Policies}

Although it is one of the smallest former Soviet republics, both demographically (3.1 million people) and geographically $(29,400$ sq $\mathrm{km})$, Armenia has thirty two identified metallic mines (gold, copper, iron, molybdenum, etc.) of which twenty-five have been granted exploitation licenses and are at different stages of operation. In addition to the twenty-five metallic mines, there are also 479 non-metallic mines which have been licensed for operation. Mining is one of the two main sectors of the Armenian economy, accounting for over half the country's exports, but the State has no stake in any of these mines and the State's sole source of revenue comes from royalty payments. Foreign investors, including American, British, Canadian, Chinese, German, and Russian companies, own the exploitation licenses for thirteen of the twenty five metallic mines and the remainder are owned by Armenian oligarchs (Safirova, 2012).

Since 1998 the Armenian Republican Party has been in power and holds the majority of seats in the National Assembly. Armenia is considered a 'semi-consolidated authoritarian' regime (Freedom House, 2014) and some have described it as a 'managed' democracy (Zolyan, 2010, Cheterian, 2009). 'Managed democracy' (upravlyayemaya demokratiya) is a phrase that was introduced by the Russian authorities in the early 2000s and is increasingly used to describe the situation in other former Soviet states (e.g., Armenia, Kazakhstan, Kyrgyzstan etc.) where the formal/procedural institutions and practices of democracies (e.g., elections) exist but are controlled and managed by the authorities (Colton and McFaul, 2003). The Armenian economy is controlled by pro-government oligarchs (Aghajanian, 2012), many 
of whom are also members of the National Assembly ${ }^{3}$ as this grants them immunity from prosecution and more importantly, allows them to shape and alter legislation in accordance with their economic interests. Although the Armenian Government has not introduced the type of repressive legislation that exists in other former Soviet countries, government officials question the probity of NGOs by accusing them of working for foreigners and being 'grant eaters' (Ishkanian 2008).

In 2012 the Government, with 'the help of the World Bank and European experts', upgraded 'the legislative framework for the country's mining sector' and adopted 'mining friendly policies' (Ministry of Energy and Armenian Development Agency, 2011: 2). Among the recently adopted 'mining friendly' policies, three stand out in particular. First, the existing environmental exploitation fee of $1.5 \%$ was abolished and companies are now only responsible for paying royalties on the sales of minerals which are levied at an incremental rate of $0.1 \%$ up to a maximum of $0.8 \%$ where an operation's profitability index exceeds $25 \%$ (Mining Journal, 2005, p. 7). What is important here is that this change in the legislative framework means that mining companies are only taxed on the sale of the products and not the amount of natural resources extracted. The royalty is calculated based on "the total estimated value generated from the sale of metallic minerals mined" (International Business Publications, 2013: 75.). Of course the amount of royalties will vary due to fluctuations in the global market price of minerals, but in the first quarter of 2012, the total amount of royalties collected by the Government was 6.3 billion drams (approximately $\$ 16$ million USD) (Safirova, 2012: 1). Given that Armenia's state budget's revenues for that year was 910 billion drams (approximately $\$ 2.46$ billion US) (News.am, 2012), it is clear that royalty payments in the mining sector are making a meagre contribution to the total budget. Second, the word 'waste' was omitted from the Mining Code and replaced with the word "lcakowyt" which translates

\footnotetext{
${ }^{3}$ The National Assembly is the legislative branch of the Armenian Government.
} 
into 'heaps' of rocks (International Business Publications, 2013), which effectively means that wastes created as a result of mining are not taxed because they are not identified as waste. Finally, mining companies have been freed from the responsibility of paying for the future maintenance of the tailing dumps, which are now considered state property. Activists argue that these reforms further weaken the State's capacity to regulate mining activity, decrease any potential benefits from mining, and intensify corruption risks (Grigoryan, 2011). The Government defends the adoption of these policies arguing that they are necessary if the country is to continue attracting foreign direct investment (Ministry of Energy and Armenian Development Agency, 2011). Mining companies meanwhile justify the privileges accorded to their sector arguing that they are bringing much needed jobs to the country and investing in infrastructural development and socially responsible projects (Lydian International, 2013, Vallex Group, 2013, Zangezur Copper Molybdenum Combine CJSC, 2013).

Although the Government continues to claim that mining leads to poverty reduction and economic growth, the evidence demonstrates the contrary in that high levels of poverty and inequality persist (Asbarez, 2013, Policy Forum Armenia, 2012, Grigoryan, 2013). According to official statistics, over $35 \%$ of Armenians live under the poverty line (i.e., live on less than \$3/day) and the unemployment rate is 7\% (World Bank, 2013, Armenian Statistical Service, 2012). Other reputable sources cite the unemployment rate in Armenia as 18.7\% (Karapetyan et al., 2011). As a lower middle-income country, Armenia has had two Poverty Reduction Strategy Papers (PRSPs), with the latest submitted in 2011 (IMF, 2011). The PRSPs have been implemented in 70 low-income countries, which are receiving debt relief under the Highly Indebted Poor Countries (HIPC) Initiative (World Bank, 2011). Armenia is not unique; similar policies have been introduced in other developing countries (Dougherty, 2011, Kuecker, 2007, Padel and Das, 2010, Campbell, 2003). What is different is that the adoption of such policies in Armenia is not only about embracing a growth- 
oriented model of development, but for demonstrating a commitment to reforming and ‘steadfastly’ moving beyond the country’s socialist past (World Bank, 2014a).

In the next section I examine why, despite the lack of benefits and the apparent dangers from mining, the Government has faced little opposition in pushing through the mining friendly policies and how activists, working through the Save Teghut Civic Initiative, are challenging and resisting these policies and practices.

\section{Resistance to Mining: the Campaign to Save Teghut}

In 2001 the Armenian Copper Programme (ACP), a Closed Joint Stock Company and subsidiary of the Vallex Group, was granted a 25-year exploitation license for the Teghut mine. The territory area allocated for mining in Teghut is 1,491 hectares, $82 \%$ of which is covered by a pristine forest. The nearest villages are Teghut and Shnogh, with a combined population of 3600. Logging began in 2009 and the mine was officially opened on 20 December 2014. Armenia's president, Serzh Sargsyan, attended the opening ceremony where he awarded a 'first-class Medal of Services to the Motherland' to the mine owner, Valery Mezhlumyan, for his 'outstanding services and weighty personal contribution to the development of economy' (president.am 2014). The president's presence at the opening ceremony indicates the government's support for the Teghut Mine. According to publicly available information, $19.3 \%$ of ACP shares belong to Mezhlumyan, while $80.7 \%$ is owned by a company registered offshore in Lichtenstein.

The environmental impact assessment (EIA) at Teghut was carried out by the Lernametalurgiai Institute (LMI), which is owned by the Vallex Group, the same company that owns the exploitation rights to the Teghut mine. Following the publication of the EIA in 2006, a number of environmental NGOs questioned the LMI's independence and argued that the EIA 'grossly undervalues' the mine and contains 'inaccurately compiled' information 
(Armenian Environmental Network, 2012). NGOs wrote letters and engaged in dialogue with government officials, but when they were unable to shift the policy on Teghut, the NGOs turned their attention to mitigating the damage rather than opposing the opening of the mine. In an interview, Martiros, an environmental NGO representative, said, 'We were against the Teghut mine and participated in the public hearings in $2007 \ldots$ today the youth is addressing the Teghut issue, not the environmental NGOs'. He went on to explain that NGOs feel constrained from engaging in what he called the 'radical' actions embraced by activists. He added, 'We are not afraid that they [officials] will punish us, but that they will obstruct our work. And we must work with and not against the Government to preserve the environment'. Stella, another environmental NGO representative also differentiated the NGOs' stance from that of the activists. She said, 'The activists are saying we don't want any mining...We recognize that mining is necessary for economic development, but we want things to happen through the proper rule of law'. For Stella, this meant pushing the Government to conduct a 'proper EIA'. Alongside environmental NGOs, other civil society actors have also been reluctant to take on the mining interests. For example, apart from a single outspoken female member of the National Assembly, opposition parties and politicians have been largely silent (Parliamentary Assembly of the Council of Europe, 2012); viable trade unions do not exist, and the Armenian Apostolic Church, which is a very important institution in Armenia (Panossian, 2006), has either remained silent or publically endorsed mining (Gabriel151036, 2012).

In 2007, young activists, disillusioned and disappointed with what they saw as a lack of resistance from political parties, environmental NGOs and other civil society actors (e.g., the Armenian Apostolic Church) to inequitable mining policies and exploitative practices, created the Save Teghut Civic Initiative (STCI). The STCI is entirely comprised of volunteers, both men and women between the ages of $22-40$ who reside in Yerevan. The 
majority of the activists are middle class professionals (including lawyers, sociologists, physicians, etc.). There are thirty-one active members in STCI and over 8000 followers on Facebook. Thirteen of the thirty-one active members of STCI (i.e., 42\%) are NGO employees. The STCI activists who are employed by NGOs have gone through capacity building training and are well versed in the discourses and practices of the aid industry, but in the context of activism around mining, they describe their actions as forms of active or 'selfdetermined' citizenship and not as NGO work.

The STCI has made repeated calls for the Government to withdraw the license for the Teghut mine and to invest in more environmentally friendly alternatives to mining (e.g., organic farming, eco-tourism, etc.). While the STCI activists are steadfastly opposed to the Teghut mine, they recognise that some mining activity in Armenia is inevitable. However, they argue that if Armenians are to benefit from mining, the State must increase taxes; strengthen regulation; stop mining projects by companies registered offshore and bring them under the 'national legal framework' so as to enhance transparency and access to information; ensure fair redistribution of profits; create effective safeguards for community oversight; and provide health insurance for miners and people living adjacent to mines (Save Teghut Civic Initiative, 2014). In order to achieve its goals, the STCI has employed various strategies ranging from protest actions; legal challenges; awareness raising and boycott campaigns; and conferences. These actions include holding protests in front of relevant ministries (e.g., the Ministry of Nature Protection and the Ministry of Energy and Natural Resources) and financial institutions funding the project (e.g., the Russian VTB Bank, the European Bank for Reconstruction and Development) (HETQ, 2010, Save Teghut Civic Initiative, 2010) and organising photography exhibitions to highlight the natural beauty of Teghut Forest so as to indicate what will be lost because of the mine (Save Teghut Civic Initiative, 2012). In January 2012 STCI activists, working with other groups, organised a 
field visit of 250 people from Yerevan and the northern city of Vanadzor to Teghut. The aim of event, which was dubbed 'Occupy Teghut' by the organisers, was to draw attention to the dangers of mining and de-forestation. Despite its name, Occupy Teghut, there was no encampment of activists and Occupy Teghut was a one-day event (Mkrtchyan, 2012). The STCI activists don't consider themselves inheritors of the Soviet era environmental movement, but as a new movement for democracy, human rights, the rule of law, and social justice. In their Manifesto they describe how they have embraced a 'rights-based approach' to 'fight against the illegitimate and unjust laws and the consequences arising from them' adding that such laws 'legitimize the existing system of corruption and exploitation' maintaining that 'reasonable use of natural resources' alongside the development of ‘alternative economic avenues' will allow for greater prosperity, social justice, democracy and the welfare of the people (Save Teghut Civic Initiative, 2012). As Amalya, a STCI activist, explained,

When you only focus on saving the forest, you lose the support of a huge number of people because the other side only has to say they are creating jobs and the argument ends. We focus on how these mining operations are stealing from the country and endangering people's health rather than the cutting of trees (Amalya).

Activists argue that the Teghut licensing process violated the Armenian Constitution and a number of national laws (e.g., the Land Code, the Law on Allocation of Mineral Resources etc.) and the Aarhus Convention on Access to Information, Public Participation in Decision-Making and Access to Justice in Environmental Matters which Armenia ratified in 2001. They refer to scientific evidence that mining is having a negative impact on public health as mining operators have largely failed to neutralise dangerous contaminants, which have been absorbed by the ground (Martinyan, 2011, American University of Armenia, 2013) and citing cases from the European Court of Human Rights, activists contend that the Teghut mine violates Article 2 (Right to Life) of the European Convention on Human Rights (Save 
Teghut Civic Initiative, 2012). In 2009, the STCI with the support of several human rights NGOs brought a lawsuit against the Armenian Government, the Ministry of Nature Protection, and the Ministry of Energy and Natural Resources, in an attempt to repeal the Teghut exploitation license. This attempt to legally challenge mining in Teghut was unsuccessful following the Cassation Court's decision in April 2011, which still stands, that civil society groups do not have the legal right to initiate lawsuits on behalf of others, regardless of their mission or stated goals (Save Teghut Civic Initiative, 2013).

Apart from attempting to raise public awareness and legally challenge mining in Teghut, since 2007, activists have been travelling from Yerevan to the villages of Teghut and Shnogh on a frequent basis so as to generate local support. Initially, they found that the local villagers, the majority of whom had sold their lands to ACP expecting in turn to receive high paying jobs, refused to engage with them. One activist explained, 'Early on, the villagers perceived us as monsters or cannibals. They would not speak to us...they thought we had come to destroy their livelihoods' (Parkev). Another activist, Anush, explained,

When we first went to Teghut [village] in 2007 I had the impression that the local people all wanted the mine to be exploited and saw it as if we [the Yerevan activists] were trying to destroy their livelihoods. Afterwards, when we began to travel to Teghut more frequently we realised who was who in the village and that some of our loudest critics were hired and sent by the Armenian Copper Programme [the mine owner]. Through Facebook they would follow our actions and they would know when we would be coming to Teghut and they would come out against us. I remember one of those people told me, "I don't care if my wife gets cancer, let the mine open and I will have a good-paying job and I can pay for her treatment" (Anush).

During interviews and focus groups conducted in Teghut and Shnogh, people spoke about their initial enthusiasm for the mine and their suspicion of the motives of the activists, but added that they were now beginning to realize the wider environmental and health impacts. People complained about the mine, but also spoke about a pervasive 'climate of 
fear' (vaxi mt'nolowrt). One focus group participant said, 'We don't like the mine, but nobody is going to join the activists, because most of the community members work in the mine and they will get fired if they join' (Male, Teghut 18-35).

While fear of reprisals is a factor, there is also a lack of faith in what civil society can achieve. As a respondent in the same focus group said, 'Why should we participate? We know that nothing is going to change anyway. It doesn't depend on you; it doesn't depend on us either' (Male, 18-30, Teghut). Meanwhile a participant in a focus group in Shnogh village said,

We don't have civil society here, not just in our village, in Armenia in general. Those people who care, who think of themselves as citizens, they are doing something...but what are we as villagers doing to change our lives? We are doing nothing. (Female, $18-35$, Shnogh). [emphasis added]

The woman above distinguished herself from the activists and when we asked her if she did not care or if she didn't think of herself as a citizen, she responded, that she was afraid of the consequences of speaking out and that she only considered herself a citizen in a formal sense (i.e., passport holder). Similar to this woman, many respondents in the fifteen focus groups spoke about their fear of joining the activists, but went on to complain about corruption, inequality, low wages, etc. Few spoke of having the capacity, let alone the right, to change things, arguing instead that if things got really bad they would emigrate. And indeed many Armenians are choosing to emigrate from Armenia to Russia, the US and countries in Western Europe (News.am, 2013, Radio Free Europe/Radio Liberty, 2010). There has long been a rural - urban divide in terms of civic activism in Armenia and elsewhere I discuss how civil society organisations, including civic initiatives, are predominantly based in the capital Yerevan and to a lesser extent in the cities of Gyumri, Vanadzor, and Goris (anonymized). Through our focus groups we found that there was widespread mistrust and fear of any kind of political activity, including participation in civil society organisations and protests. In 
2012 STCI adopted a strategy aimed at building stronger ties with the communities through creating alternative forms of economic development. Since then the group has organised the sale of locally produced goods (e.g., honey, handicrafts, etc.) which has been well received by locals, but the impact should not be exaggerated. Activists recognize that the villagers' recent willingness to engage with them is less related to their efforts and more to how local people are recognising the dangers of mining and its effects on their health and the wider environment. In an interview in 2013, Narine, an activist said,

The change didn't come as a result of our actions, but because of time. The things we predicted were proved right. People are now convinced by their own experiences. On our last visit people did not kick us out anymore. This was a signal to me that I can easily enter the community, talk to people, and inform them more. I take it as my duty no matter what the result will be. I will go to the community and provide them with the information I have (Narine).

After eight years of campaigning, the antagonistic relationship which initially existed between the local communities and activists has given way to less hostile interactions. One Teghut villager said, 'When the activists first came from Yerevan, I blocked their way with my flag, and didn't let them get into the village. Now I regret it' (Hapet). Despite the improved relations, the resistance to mining is still organised and led by the STCI activists in Yerevan with limited involvement from villagers in Teghut and Shnogh, although this is beginning to change. The hitherto lack of active participation by local villagers has allowed the government and mining companies to criticise the STCI activists and those who are challenging other mines (e.g., Amulsar, Kajaran, etc.) and to question their legitimacy. For instance, in an open letter sent by Hratch Jabrayan, the Vice President of the Canadian owned Deno Gold Mining Company, to a Canadian Armenian youth volunteer, Jabrayan writes:

Don't lose yourself and become the victim of those "activists", who are carrying out the orders of foreign governments in their desire to obtain grants (Jabrayan, 2013). 
Such arguments which attempt to describe environmental activists in Armenia as 'carrying out the orders of foreigners' are not only very similar to the critiques lodged against NGOs (i.e., 'grant eaters') (Ishkanian 2008), but they also conveniently overlook the fact that it is the mining companies themselves that are often owned and operated by foreign or multinational corporations and that the current 'mining friendly' policies in Armenia are being 'upgraded', as stated earlier, with the 'help of the World Bank and European experts' (Ministry of Energy and Armenian Development Agency, 2011:2). Activists respond to such criticisms by arguing that natural resources are public goods and that all citizens of Armenia, regardless of where they reside, have the right to have a voice in the management and extraction of natural resources.

While the STCI did not stop the Teghut mine from opening, after eight years of campaigning, they have succeeded in raising awareness of and generating debate about the actual impacts and benefits of mining specifically and about neoliberal development policies and practices more generally (American University of Armenia, 2013, ARF Shant Student Association, 2012b, ARF Shant Student Association, 2012a) and are now recognized as 'stakeholders' in mining (World Bank, 2014b, Save Teghut Civic Initiative, 2014). In 2012, they even received their first celebrity endorsement, when singer Serj Tankian, formerly of the US rock band System of A Down, released a video in which he discusses the risks of mining in Teghut (Teghut Save, 2012).

\section{Challenging the Gospel of Neoliberalism}

Stiglitz has criticised what he calls the 'market fundamentalism' that was embraced by international development agencies, arguing that the policies which were formulated and introduced in the former socialist countries (as well as globally) were based on a 'curious blend of ideology and bad economics' and 'open, frank discussion was discouraged' 
(Stiglitz, 2003, iv). Many scholars studying the post-socialist transitions have analysed how those promoting the transitions in the former Soviet countries were driven by an unshakable belief that unfettered markets maximize individual freedom and that they are the best means of development (Hann, 2002, Mandel, 2012, Wedel, 1998). As Mandel writes,

The developers and their acolytes share a faith that they are moving out of bad thinking and into enlightened thinking...Elsewhere in developing countries local development professionals have sometimes been able to adopt critical postures towards some of the ideas and messages of the developers, whereas in Central Asia much more is taken as gospel (2002: 294).

Activists recognise the influence of international development agencies in shaping these policies and in a recent statement demanded that the World Bank 'conduct an audit of its 20 year engagement in Armenia' so as to assess its impact on Armenia's development (Save Teghut Civic Initiative, 2014). While activists criticize the World Bank and other donors for introducing neoliberal policies which have shaped development policies and practices in Armenia, they are far more critical of Armenian government officials for their willingness to adopt those policies. For instance, Norair, an activist, said,

I think international financial organisations are immoral. The policies they have introduced means that a State does not exist in Armenia and that Armenia is completely unprotected from foreign corporations that impoverish the people (Norair).

He went on to add, 'This is not to say that I think our government officials are so stupid to allow Armenia's gold, silver and other metals to be taken by foreigners and for them to not profit from that process; they are also involved in the plunder.' For many activists the problem is that the State has ceded its responsibilities and is not behaving like 'a proper State' (i.e., a state which promotes and defends the interests of its population) (Erik). One activist, Parkev, explained, '...the corporations don't give a damn about the long-term impacts, they just come in and take our resources. We need a State that will be concerned about the impact and will have a plan of action.' Meanwhile another activist explained, 
The Armenian Government is offering a commodity to corporations that theoretically belongs to all Armenians. For Armenia to benefit, the Government would have to tax the corporations, but instead the Armenian Government has set it up such that it is literally gifting the resources to the mining industry. And rather than channel the revenues to the state budget to benefit all Armenians, the money is being funnelled into the pockets of a few oligarchs...I use the word 'theft' to describe this situation because it is the stealing of all Armenians' revenues (Abisoghom).

Given the investment in civil society building of the past two decades which led to the rapid growth of NGOs, it is not unreasonable to expect NGOs to have taken stronger action in holding the State to account. But as I have discussed, environmental NGOs have been passive and limited their activities to formal, non-confrontational, consensual practices of policy dialogue. Many activists expressed their disappointment with the NGOs' lack of action. One activist said, 'I won't be exaggerating if I tell you that there is a serious 'climate of fear' preventing NGOs from seriously tackling mining issues...instead they say 'we're focusing on our projects' (Tigran). While another argued, 'Environmental NGOs have the resources to put up a stronger fight against mining, but it's only activists who are doing anything. NGOs are too dependent on their grants...they prefer to drive around in their Jeeps, instead of putting their comfort and funding at risk (Anush). Narine, an activist who also works in human rights NGO, was less harsh in her criticism of NGOs. She argued,

...[NGOs] were not able to or did not seek to demonstrate activeness...This is demonstrated by the fact that things are only changing due to young active citizens, who are more persistent and mobile. Young citizens are free from documentation, from writing grants, reports... there are no NGOs involved in the issue of Teghut. There are only representatives from NGOs, but that is because of their own initiative (Narine).

But the situation is not so black and white in Armenia, with NGOs on one side and activists on the other. Indeed, activists have greater autonomy and are not bound by the accountability and reporting requirements facing NGOs, but NGOs (albeit primarily human rights groups and not environmental NGOs) have provided behind the scenes support to the activists, including providing meeting spaces, contacts, or research support. Moreover, as 
discussed earlier, $42 \%$ of the STCI activists are NGO employees, but their participation in STCI is, as Narine quoted above says, 'of their own initiative'. One such activist, Erik, who works in an international NGO said,

... the core of it is taking responsibility for the problems and saying here on out I am going to maximize my agency as a citizen and do whatever I possibly can to make sure that this bad thing [the mine] doesn't happen.

The key difference between the NGOs and the activists is that the latter reject the NGOs' non-confrontational, formal practices of policy advocacy and instead, by exercising their 'right to have rights' (Arendt, 1951), they are demanding greater responsibility and accountability from the State. By engaging in direct action, they are challenging not only the policies and practices in Armenia's mining sector, but also the underlying assumptions and politics which inform development policies more broadly as well as existing State-society relations. There are also important differences between the activists and the local villagers living near mining sites. Unlike the activists, most of the respondents in the fifteen focus groups did not see themselves as rights bearing citizens and argued that it was the State's role to shape and deliver economic and social policies. Some have argued that such expectations from the State indicate 'nostalgia' for the Soviet past (Dudwick et al., 2003: 25), but the activists, who are demanding greater responsibility and accountability from the State, are not acting out of nostalgia for the Soviet past nor are they arguing for a return to socialism. They argue that by claiming their rights, they are acting as responsible citizens and that they are demonstrating their committed to democracy. Moreover, for the activists, their struggle is not against the free market per se, but around the corruption, lawlessness, and oligarchy which characterize the policies and practices of the neoliberal state in Armenia. As Erik quoted above argues, what the activists want most is for the State to behave like a 'proper State' and to promote and defend the rights and interests of its citizens. 


\section{Conclusion}

In this article I examined how neoliberalism is manifested in Armenia and analysed the civil society resistance against neoliberal practices and policies in the mining sector. I argued that in contrast to the passive, non-confrontational and formalistic engagement of environmental NGOs, the STCI activists have introduced new understandings and practices of civic activism and have opened up debates about the meaning of development and the roles and responsibilities of the State and citizens in that process. They have framed their campaign using rights based discourses arguing that their struggle against mining is not solely about protecting the environment, but that it concerns the lack of democracy, social justice and the rule of law in Armenia. As I discussed, apart from their ties to Armenian diaspora organisations, the STCI and other civic initiatives was not strongly connected to global civil society networks or activists. While the group's tactics, repertories of action, and even discourses and slogans (e.g., Occupy Teghut) drew on and reflected global trends and practices, activists also modified and adapted them to fit the local context. Even so, this movement in Armenia is part of the wider global struggles against neoliberalism and for democracy that have emerged since the late $20^{\text {th }}$ century. As I demonstrated, the STCI was not able to stop the mine from opening or indeed to have an impact at the policy or legislative level. As social movement scholars have demonstrated, while protest groups and social movements can have an impact at the policy level, such impact usually comes about as a result of shifts in public opinion; the forging of vertical and horizontal alliances (including with political parties); and in identifying and taking advantage of political windows of opportunity (Castells, 2012, Tarrow, 2011, Tilly and Tarrow, 2007, Goodwin and Jasper, 2012, Giugni, 1998). However, as I argued, although the STCI failed to stop the mine from opening, it would be a mistake to describe the campaign as a failure because in rejecting the hitherto accepted formal, non-confrontational practices of NGO advocacy, the activists have 
created new subjectivities and practices for activism, a democratic politics of dissensus, and begun to challenge the hegemony of neoliberalism which heretofore was above reproach and beyond critique.

It remains to be seen how this new phase of democratic politics and contentious collective action will develop. In follow-up interviews with activists in 2014 and 2015, I found that STCI activists were considering how to increase their effectiveness and impact at the policy level. Some are now actively engaged in creating a new trade union which will organise to defend the rights of mine workers; a few have joined a new opposition political party, the Civil Contract, that was launched in May 2015; and most recently, the group became involved in a new court case concerning the legality of the Teghut Mine. In July 2015 STCI announced that it had obtained 'legally significant evidence that affirms the fact that operation of Teghut mine violates Armenian and international legislation' and citing a number of documents as well as aerial pictures of the mine, it claimed that there is now 'irrevocable evidence that the mine is illegally operated' (Save Teghut Civic Initiative 2015). The emergence of this new evidence and the satellite photographs has prompted the Administrative Court of Armenia to hear a new case on the matter of the Teghut Mine. Given that the Cassation Court's ruling that civil society groups do not have the legal right to initiate lawsuits on behalf of others still stands, the new case was filed by a number of Shnogh villagers (Save Teghut Civic Initiative 2015). This new development indicates that a more productive relationship has been forged between the activists and the local community.

Scholars writing about developmental states and regimes in Latin America have begun to discuss the emergence of post-neoliberalism (Bebbington and Bebbington, 2010, Grugel and Riggirozzi, 2012, Peck et al., 2010, Wylde, 2012), defining it as a 'different conceptualization of the state' (Grugel and Riggirozzi, 2012: 3) or a 'new form of social 
contract between the state and people' (Wylde, 2011: 436). In the context of post-socialist countries such as Armenia, where the challenges to neoliberal ideas and the market economy are only emerging now, after nearly a quarter of a century of transition, the struggle against neoliberalism and the post-political consensus has only just begun.

References

ABRAHAMIAN, L. (ed.) 2005. Armenian Identity in a Changing World Costa Mesa, CA: Mazda Publishers.

AGHAJANIAN, L. 2012. Breaking the Grip of the Oligarchs. Foreign Policy, online publication.

ALI, S.H. \& A.S. GREWAL. 2006. The Ecology and Economy of Indigenous Resistance: Divergent Perspectives on Mining in New Caledonia. The Contemporary Pacific, 18, 2, 361-392.

AMERICAN UNIVERSITY OF ARMENIA. 2013. AUA Evaluates 25 Toxic Waste Sites Near Communities in Armenia [Online]. Available: http://newsroom.aua.am/2013/04/04/aua-evaluates-25-toxic-waste-sites-nearcommunities-in-armenia/ [Accessed 4 May 2013.

ARF SHANT STUDENT ASSOCIATION. 2012a. Saving Teghut: Environmental Justice in Armenia [Online]. Available: https:// HYPERLINK "http://www.facebook.com/events/381715415189706/"www.facebook.com/events/38 1715415189706/ [Accessed 10 June 2013].

ARF SHANT STUDENT ASSOCIATION. 2012b. Stop the Destructive Mining in Armenia [Online]. Facebook. Available: https:// HYPERLINK "http://www.facebook.com/events/421100084605388/"www.facebook.com/events/42 1100084605388/ [Accessed 25 April 2013 2012].

ARMENIAN ENVIRONMENTAL NETWORK 2012. Teghut Mine in Armenia - an Ecological and Human Rights Disaster. Washington, DC: Armenian Environmental Network

ARMENIAN STATISTICAL SERVICE 2012. The Socio-Economic Situation in the Republic of Armenia 2011 - January - June Yerevan, Armenia.

ASBAREZ. 2013. Mining in Armenia Creates Poverty, Says Study [Online]. Los Angeles. Available: http://asbarez.com/109448/mining-in-armenia-creates-poverty-says-study/.

BABAJANIAN, B. V. 2005. Civic participation in post-Soviet Armenia. Central Asian survey, 24, 261-279.

BANKS, G. 2014. Drilling and Digging: Extractive Industries and Development. Development and Change, 45, 191-204.

BARRY, A., OSBORNE, T. \& ROSE, N. 1996. Foucault and political reason: Liberalism, neoliberalism and rationalities of government, London, UCL Press.

BEBBINGTON, A. \& BEBBINGTON, D. H. 2010. An Andean Avatar: Post-neoliberal and neoliberal strategies for promoting extractive industries. In: INSTITUTE, U. O. M. B. W. P. (ed.). Manchester. 
BEBBINGTON, A., BORNSCHLEGL, T. \& JOHNSON, A. 2013. Political Economies of Extractive Industry: From Documenting Complexity to Informing Current Debates. Development and Change, Virtual Issue 2, 1 - 16.

BEBBINGTON, A., HINOJOSA, L., BEBBINGTON, D. H., BURNEO, M. L. \& WARNAARS, X. 2008a. Contention and ambiguity: mining and the possibilities of development. Development and Change, 39, 887-914.

BEBBingtON, A. J., BEBBINGTON, D. H., BURY, J., LINGAN, J. \& MUNOZ, J. P. 2008b. Mining and Social Movements: Struggles Over Livelihood and Rural Territorial Development in the Andes. World Development, 36, 2888-2905.

BOJICIC-DZELILOVIC, V., KER-LINDSAY, J. \& KOSTOVICOVA, D. (eds.) 2013. Civil Society and Transitions in the Western Balkans, London: Palgrave.

BRIDGE, G. 2004. Mapping the Bonanza: Geographies of Mining Investment in an Era of Neoliberal Reform. The Professional Geographer, 56, 406-421.

CAMPBELL, B. 2003. Factoring in Governance is Not Enough. Mining Codes in Africa, Policy Reform and Corporate Responsibility. Minerals and Energy, 18, 2-13.

CARMIN, J. \& FAGAN, A. 2010. Environmental mobilisation and organisations in postsocialist Europe and the former Soviet Union. Environmental Politics, 19, 689-707.

CAROTHERS, T. 1999. Aiding Democracy Abroad: The Learning Curve, Washington, DC, Carnegie Endowment for International Peace.

CASTELLS, M. 2012. Networks of Outrage and Hope: Social Movements in the Internet Age, Cambridge, Polity.

CAUCASUS RESEARCH RESOURCE CENTER 2010. Caucasus Barometer. Yerevan: CRRC.

CELICHOWSKI, J. 2004. Civil society in Eastern Europe: growth without engagement'. In: GLASIUS, M., LEWIS, D. \& SECKINELGIN, H. M. (eds.) Exploring Civil Society: Political and Cultural Contexts. London: Routledge.

CENTRE FOR CIVIL SOCIETY. 2010. LSE Centre for Civil Society "What is civil society?" [Online].

Available: http://www.webarchive.org.uk/wayback/archive/20100820110538/http://www.lse.ac. uk/collections/CCS/introduction/default.htm [Accessed 5 August 2013].

CHETERIAN, V. 2009. From reform and transition to 'coloured revolutions. The journal of communist studies and transition politics, 25.

CÍSA movement organisations in the Czech Republic after the fall of Communism. Environmental Politics, 19, 736-755.

ÇOBAN, A. 2004. Community-based ecological resistance: the Bergama movement in Turkey. Environmental politics, 13, 438-460.

COLTON, T. J. \& MCFAUL, M. 2003. Popular Choice and Managed Democracy: the Russian Elections of 1999 and 2000. Washington, DC: Brookings Institution Press.

CONDE, M. \& KALLIS, G. 2012. The global uranium rush and its Africa frontier. Effects, reactions and social movements in Namibia. Global environmental change, 22, 596610.

COUNTERPART INTERNATIONAL 2010. Impact of Environmental Organizations on Policy Change in Armenia. Yerevan: Counterpart International.

DOUGHERTY, M. L. 2011. The Global Gold Mining Industry, Junior Firms, and Civil Society Resistance in Guatemala. Bulletin of Latin American Research, 30, 403-418.

DUDWICK, N., GOMART, E., MARC, A. \& KUEHNAST, K. (eds.) 2003. When Things Fall Apart: Qualitative Studies of Poverty in the Former Soviet Union, Washington, DC: The World Bank 
EBRD 2012. Strategy for Armenia: document approved by the Board of Directors on 29 May 2012.

EVANS JR., A. B. 2012. Protests and civil society in Russia: the struggle for the Khimki Forest. Communist and post communist studies, 45, 233-242.

FERGUSON, J. 2009. The Uses of Neoliberalism. Antipode`, 41, 166-184.

FREEDOM HOUSE. 2014. Armenia [Online]. Available: http://www.freedomhouse.org/report/nations-transit/2013/armenia\#.U2iirV9wbGg.

GABRIEL151036 2012. Video - The Leader of the Gugarants Diocese "I was deeply overjoyed..."

GIUGNI, M. G. 1998. Was it worth the effort? The Outcomes and Consequences of Social Movements. Annual Review of Sociology, 24, 371-393.

GLASIUS, M. AND ISHKANIAN, A. 2015." Surreptitious symbiosis: engagement between activists and NGOs" in VOLUNTAS: International Journal of Voluntary and Nonprofit Organizations, Vol. 26, N. 6. 2620-2644.

GOODWIN, J. \& JASPER, J. M. (eds.) 2012. Contention in Context: political opportunities and the emergence of protest, Palo Alto: Stanford.

GOOLOBA-MUTEBI, F. \& HICKEY, S. 2010. Governing Chronic Poverty under Inclusive Liberalism: The case of the Northern Uganda Social Action Fund. The Journal of Development Studies, 46, 1216-1239.

GORDON, T. \& WEBBER, J. 2008. Imperialism and resistance: Canadian mining companies in Latin America. Third World quarterly, 29, 63-87.

GREENBERG, J. 2010. There's Nothing Anyone Can Do About It: Participation, Apathy and 'Successful' Democratic Transition in Postsocialist Serbia. Slavic Review, 69, 41-64.

GRIGORYAN, A. 2013. The impact of mining sector on growth, inequality and poverty: evidence from Armenia. Yerevan, Armenia AUA Acopian Center for the Environment

GRIGORYAN, E. 2011. Mining: An Economic Engine or Path to Ruin [Online]. hetq.am. Available: http://hetq.am/eng/print/3487/ [Accessed 5 September 2013].

GRUGEL, J. \& RIGGIROZZI, P. 2012. Post-neoliberalism in Latin America: Rebuilding and reclaiming the state after crisis. Development and Change, 43, 1-21.

HANN, C. (ed.) 2002. Postsocialism: Ideals, Ideologies and Practices in Eurasia, London: Routledge.

HANSEN, G. 1996. USAID Evaluation Highlights No. 56: Constituencies for Reform: Strategic Approaches for Donor-Supported Civic Advocacy Programs. Washington, DC: USAID.

HARVEY, D. 2007. A Brief History of Neoliberalism, Oxford, Oxford University Press.

HAQUE, S. 2008. Global Rise Of Neoliberal State And Its Impact On Citizenship: Experiences In Developing Nations. Asian Journal of Social Science 36 11-34.

HEMMENT, J. 2004. The Riddle of the Third Sector: Civil Society, International Aid, and NGOs in Russia. Anthropological Quarterly, 77, 215-241.

HEMMENT, J. 2012. Soviet-style Neoliberalism? Nashi, Youth Voluntarism, and the Restructuring of Social Welfare in Russia. Problems of Post-Communism, 56, 6, 36-50.

HENRY, L. A. 2002. Two Paths to a Greener Future: Environmentalism and Civil Society Development in Russia. Demokratizatsiya, Spring 10, 184-206.

HENRY, L. A. 2010. Between transnationalism and state power: the development of Russia's post-Soviet environmental movement. Environmental Politics, 19, 756-781.

HETQ. 2010. Teghut Defense Group to Stage Protest Outside VTB Bank [Online]. hetq.am. Available: http://hetq.am/eng/news/46330/teghut-defense-group-to-stage-protest-outside-vtbbank.html [Accessed 11.11.2015. 
HICKEY, S. 2010. The Government of Chronic Poverty: From Exclusion to Citizenship? The Journal of Development Studies, 46, 1139-1155.

HILGERS, M. 2012. The historicity of the neoliberal state. Social Anthropology, 20, 80-94.

HOLDEN, W. N. 2005. Civil Society Opposition to Nonferrous Metals Mining in the Philippines. Voluntas, 16, 223-249.

HOLDEN, W. N. \& JACOBSON, R. D. 2008. Civil Society Opposition to Nonferrous Metals Mining in Guatemala. Voluntas, 19, 325-350.

HURLEY, P. T. \& ARI, Y. 2011. Mining (Dis)amenity: The Political Ecology of Mining Opposition in the Kaz (Ida) Mountain Region of Western Turkey. Development and Change, 42, 1393.

IMF. 2011. IMF Country Report 11/191 - Republic of Armenia: Poverty Reduction Strategy Paper - Progress Report [Online]. Available: http://www.imf.org/external/pubs/ft/scr/2011/cr11191.pdf [Accessed 01 June 2014.

INTERNATIONAL BUSINESS PUBLICATIONS 2013. Mineral, Mining Sector and Business Guide: Volume 1 - Strategic Information and Regulations. Washington, DC: International Business Publications.

ISHKANIAN, A. 2008. Democracy Building and Civil Society in Post-Soviet Armenia. London: Routledge.

ISHKANIAN, A. 2015. "Self-Determined Citizens? New Forms of Civic Activism and Citizenship in Armenia" in Europe Asia Studies, Vol. 67, N. 8, 1203-1227.

JABRAYAN, H. 2013. Open Letter from Hratch Jabrayan, the Director of the Deno Gold Mining Corporation, to Canadian Armenia Sevak Harutyunyan. ed. Circulated by the Armenian Ecological Front.

KALDOR, M. 2003. Global Civil Society: An Answer to War, Cambridge, Polity Press.

KARAPETYAN, S., MANASYAN, H., MIRZAKHANYAN, A., NOREKIAN, M. \& HARUTYUNYAN, N. 2011. Armenia: Social Protection and Social Inclusion COUNTRY REPORT. Yerevan: Eurasia Partnership Foundation and Caucasus Research Resource Center.

KUECKER, G. D. 2007. Fighting for the Forests: Grassroots Resistance to Mining in Northern Ecuador. Latin American Perspectives, 34, 94-107.

LUTSEVYCH, O. 2013. How to Finish a Revolution: Civil Society and Democracy in

Georgia, Moldova and Ukraine. London: Chatham House.

LYDIAN INTERNATIONAL. 2013. Environmental and Social [Online]. Available: http://www.lydianinternational.co.uk/environmental.htm.

MALKHASIAN, M. 1996. Gha-Ra-Bagh: The Emergence of the National Democratic

Movement in Armenia. Detroit.: Wayne State University.

MANDEL, R. 2002. Seeding civil society. In: HANN, C. (ed.) Postsocialism: Ideals, ideologies and practices in Eurasia. London: Routledge.

MANDEL, R. 2012. Introduction: Transition to Where? Developing Post-Soviet Space. Slavic Review, 71, 223-233.

MARANGOS, J. 2002. The Political Economy of Shock Therapy. Journal of Economic Surveys, 16, 41-76.

MARTINYAN, I. 2011. Academy of Science Experts - Armenia Faces Pollution Crisis. HETQ [Online]. Available: http://old.hetq.am/en/ecology/bn-26/.

MENDELSON, S. E. \& GLENN, J. K. (eds.) 2003. The Power and Limits of NGOs: A Critical Look at Building Democracy in Eastern Europe and Eurasia., New York: Columbia University Press.

METAL BULLETIN 2005. Armenia: new opportunities for the mining industry in the ancient land. Metal Bulletin Monthly, 16-17. 
MINING JOURNAL. 2005. Armenia [Online]. London: Mining Communications LTD. Available:

http://www.infomine.com/library/publications/docs/MiningJournalNov2005.pdf.

MINISTRY OF ENERGY AND ARMENIAN DEVELOPMENT AGENCY 2011. Mining Industry in Armenia 2011. Yerevan.

MKRTCHYAN, G. 2012. Occupy Teghut?: Year begins with new protest of mining exploitation [Online]. armenianow.com. Available:

http://armenianow.com/social/environment/34551/armenia_teghut_foreign_environm ent campaign [Accessed 11.11.15.

MOODY, R. 2007. Rocks \& Hard Places: The globalization of mining, London, Zed.

MORJÉ HOWARD, M. 2003. The Weakness of Civil Society in Post-Communist Europe, Cambridge, Cambridge University Press.

MOUFFE, C. 2005. On the Political. London: Routledge.

NEWS.AM. 2012. Armenian draft state budget 2012 is made public [Online]. Available: http://news.am/eng/news/75781.html [Accessed 11 November 2015.

NEWS.AM. 2013. Emigration from Armenia grows News.am.

NIKTIN, V. 2010. The New Civic Activism in Russia. The Nation.

O'CONNOR, D. \& BOHORQUEZ MONTOYA, J. P. 2010. Neoliberal transformation in Colombia's goldfields: development strategy or capitalist imperialism? Labour, capital and society, 43, 85-118.

ONG, A. 2006. Neoliberalism as Exception: Mutations in Citizenship and Sovereignty, Durham, NC, Duke University Press.

PADEL, F. \& DAS, S. 2010. Cultural genocide and the rhetoric of sustainable mining in East India. Contemporary South Asia, 18, 333-341.

PANOSSIAN, R. 2006. The Armenians: From Kings and Priest to Merchants and Commissars, London, Hurst Company.

PARLIAMENTARY ASSEMBLY OF THE COUNCIL OF EUROPE 2012. Doc. 12847 Condemnation of the man-made ecological disaster project of Teghut - written declaration No. 503. PACE.

PECK, J., NIK, T. \& BRENNER, N. 2010. Postneoliberalism and its Malcontents. Antipode`, 41, 94-116.

POLICY FORUM ARMENIA 2012. Armenia: Averting an Economic Catastrophe Washington, DC: Policy Forum Armenia

PORTER, D. \& CRAIG, D. 2004. The third way and the third world: poverty reduction and social inclusion in the rise of 'inclusive' liberalism. Review of International Political Economy, 11, 387-423.

PRESIDENT.AM. 2014. President Serzh Sargsyan's working visit to Lori Marz. 20 December. Available:

http://www.president.am/en/press-release/item/2014/12/20/President-Serzh-Sargsyan-visitLori/ Accessed 10 February 2015.

RADIO FREE EUROPE/RADIO LIBERTY. 2010. UN Report Warns Of 'New Wave' Of Emigration From Armenia. 11 May 2010.

RANCIERE, J. 2010. Dissensus: On Politics and Aesthetics, London, Continuum.

RASCH, E. D. 2012. Transformations in citizenship: local resistance against mining projects in Huehuetenango (Guatemala). Journal of developing societies, 28, 159-184.

RAZSA, M. \& KURNIK, A. 2012. The Occupy Movement in Žižek's hometown: Direct democracy and a politics of becoming. American Ethnologist, 39, 238-258.

RUMIN, V. 2000. Mining Annual Review. The Mining Journal. London.

SAFIROVA, E. 2012. The Mineral Industry of Armenia. In: YEARBOOK, U. G. S. M. (ed.). Washington, DC: US Geology Survey. 
SALMI, O. 2008. Drivers for adopting environmental management systems in the post-Soviet mining industry. International Environmental Agreement, 8, 51-77.

SAMPSON, S. 1996. The Social Life of Projects. In: HANN, C. \& DUNN, E. (eds.) Civil Society: Challenging Western Models,. London: Routledge.

SAVE TEGHUT CIVIC INITIATIVE. 2010. Protest demontsration in front of the EBRD (European Bank for Reconstruction and Development) bank [Online]. Available: http://teghut.am/en/2010/08/protest-demontsration-in-front-of-the-ebrd-europeanbank-for-reconstruction-and-development-bank-3/ [Accessed 11.11.15.

SAVE TEGHUT CIVIC INITIATIVE. 2012. http://teghut.am/en/2012/10/teghut-days-atmashtots-park/ [Online]. Available: http://teghut.am/en/2012/10/teghut-days-atmashtots-park/ [Accessed 11.11.15.

SAVE TEGHUT CIVIC INITIATIVE 2012. What we Stand For. Yerevan: Save Teghut Civic Initiative.

SAVE TEGHUT CIVIC INITIATIVE. 2013. Legal Processes [Online]. Available: http://teghut.am/en/legal-processes.

SAVE TEGHUT CIVIC INITIATIVE. 2014. Statement: On the occasion of the conference "Responsible Mining in Armenia: Opportunities and Challenges" [Online]. Available: http://alter-conference.teghut.am/press-release/.

SAVE TEGHUT CIVIC INITIATIVE. 2015. Press release of film and new court case. Available:http://teghut.am/en/2015/07/press-release-film-and-new-administrativecase-on-teghut/ Accessed 10 August 2015.

SIEDER, R. 2010. Legal Cultures in the (UN) Rule of Law: Indigenous Rights and Juridification in Guatemala. In: COUSO, J., HUNEUS, A. \& SIEDER, R. (eds.) Cultures of Legality: Judicialization and Political Activism in Latin America. NY: Cambridge University Press.

STIGLITZ, J. 2003. Globalization and it Discontents, New York, W.W. Norton \& Company. TARROW, S. 2011. Power in Movement Cambridge, Cambridge University Press.

TILLY, C. \& TARROW, S. 2007. Contentious Politics, Boulder: Paradigm Publishers.

TEGHUT SAVE. 2012. Serj Tankian in defense of Teghut Forest [Online]. You Tube. Available: https:// HYPERLINK "http://www.youtube.com/watch?v=hGEmj2PQPkQ"www.youtube.com/watch?v=hG Emj2PQPkQ [Accessed 15 April 2013.

THE ECOLOGIST. 2013. Romania rejects Rosia Montana gold mine [Online]. Available: http://www.theecologist.org/News/news_round_up/2196555/romania_rejects_rosia_m ontana_gold mine.html.

THE ECONOMIST 1998. Presidents Come...(and presidents go). The Economist.

US AGENCY FOR INTERNATIONAL DEVELOPMENT 1999. Lessons in Implementation: The NGO Story - Building Civil Society in Central and Eastern Europe and the New Independent States. Washington, DC: Office of Democracy and Governance.

VALLEX GROUP. 2013. Corporate Social Responsibility [Online]. Available: http://www.teghout.am/en/development.htm [Accessed 25 April 2013].

VELICU, I. 2012. To sell or not to sell: landscapes of resistance to neoliberal globalization in Transylvania. Globalizations, 9, 307-321.

WACQUANT, L. 2012. Three steps to a historical anthropology of actually existing neoliberalism. Social Anthropology, 20, 66-79.

WALKER, E. W. 1998. Armenia's "Constitutional Coup" and the Karabakh Conflict. Berkeley, CA: Institute of Slavic, East European, and Eurasian Studies.

WEDEL, J. R. 1998. Collision and Collusion: The Strange Case of Western Aid to Eastern Europe, New York, St. Martin's Press 
WEINTHAL, E. \& LUONG, P. J. 2006. Combating the Resource Curse: An Alternative Solution to Managing Mineral Wealth. Perspectives on Politics, 4, 35-53.

WORLD BANK 2002. Mining and Development: Large Mines and Local Communities: Forging partnerships, building sustainability. Washington DC: World Bank.

WORLD BANK 2004. Civic Engagement to Improve Development Effectiveness in the Europe and Central Asia Region: the Role of the World Bank. Washington, DC: World Bank.

WORLD BANK. 2011. PRSP Sourcebook [Online]. Available: http://web.worldbank.org/WBSITE/EXTERNAL/TOPICS/EXTPOVERTY/EXTPRS/ 0, contentMDK:20175742 menuPK:490516 pagePK:148956 piPK:216618 theSiteP K:384201,00.html [Accessed 10 November 2015.

WORLD BANK. 2013. Armenia data [Online]. Available: http://data.worldbank.org/country/armenia.

WORLD BANK. 2014a. Building a More Sophisticated Market Economy [Online]. Available:

http://web.worldbank.org/WBSITE/EXTERNAL/EXTABOUTUS/IDA/0,,contentMD K:22297622 menuPK:4754051 pagePK:51236175 piPK:437394 theSitePK:73154, 00.html.

WORLD BANK. 2014b. Press Release: Responsible Mining in Armenia: Opportunities and Challenges [Online]. Available: http://www.worldbank.org/en/news/pressrelease/2014/03/25/responsible-mining-in-armenia [Accessed 4 April 2014.

WYLDE, C. 2011. State, Society and Markets in Argentina. Bulletin of Latin American Research, 30, 436-45.

WYLDE, C. 2012. Latin America after Neoliberalism: Developmental Regimes in PostCrisis States, Basingstoke, Palgrave/Macmillan.

ZANGEZUR COPPER MOLYBDENUM COMBINE CJSC. 2013. Available: http://www.zcmc.am/eng/sustainability/social-programs/

ZIZEK, S. 1999. The Ticklish Subject: The Absent Centre of Political Ontology. London: Verso.

ZOLYAN, M. 2010. Armenia in O. BEACHAIN, D. \& A. POLESE (eds.) The Colour Revolutions in the Former Soviet Republics: Successes and Failures. London: Routledge. 